\title{
Correction to: Visible lattice points along curves
}

\author{
Kui Liu ${ }^{1} \cdot$ Xianchang Meng ${ }^{2}(-)$
}

Published online: 27 July 2021

(C) The Author(s) 2021

\section{Correction to: The Ramanujan Journal https://doi.org/10.1007/s11139-020-00302-w}

The article "Visible lattice points along curves", written by Kui Liu and Xianchang Meng, was originally published electronically on the publisher's internet portal on 27 July 2020 without open access. With the author(s)' decision to opt for Open Choice the copyright of the article changed on 9 July 2021 to () The Author(s) 2020 and the article is forthwith distributed under a Creative Commons Attribution 4.0 International License, which permits use, sharing, adaptation, distribution and reproduction in any medium or format, as long as you give appropriate credit to the original author(s) and the source, provide a link to the Creative Commons licence, and indicate if changes were made. The images or other third party material in this article are included in the article's Creative Commons licence, unless indicated otherwise in a credit line to the material. If material is not included in the article's Creative Commons licence and your intended use is not permitted by statutory regulation or exceeds the permitted use, you will need to obtain permission directly from the copyright holder. To view a copy of this licence, visit http://creativecommons.org/ licenses/by/4.0.

Open Access This article is licensed under a Creative Commons Attribution 4.0 International License, which permits use, sharing, adaptation, distribution and reproduction in any medium or format, as long as you give appropriate credit to the original author(s) and the source, provide a link to the Creative Commons licence, and indicate if changes were made. The images or other third party material in this article

The original article can be found online at https://doi.org/10.1007/s11139-020-00302-w.

Xianchang Meng

xianchang.meng@uni-goettingen.de

Kui Liu

liukui@qdu.edu.cn

1 School of Mathematics and Statistics, Qingdao University, 308 Ningxia Road, Shinan District,

Qingdao, Shandong, China

2 Mathematisches Institut, Georg-August Universität Göttingen, Bunsenstraße 3-5, 37073 Göttingen, Germany 
are included in the article's Creative Commons licence, unless indicated otherwise in a credit line to the material. If material is not included in the article's Creative Commons licence and your intended use is not permitted by statutory regulation or exceeds the permitted use, you will need to obtain permission directly from the copyright holder. To view a copy of this licence, visit http://creativecommons.org/licen ses/by/4.0/.

Publisher's Note Springer Nature remains neutral with regard to jurisdictional claims in published maps and institutional affiliations. 